\title{
Character of Children Discipline in Learning Drawing
}

\author{
Farida Mayar
}

\author{
Early Childhood Education Department, Padang State University, Padang, Indonesia \\ mayarfarida@gmail.com
}

\begin{abstract}
Character discipline of children in learning to draw aims to find out the discipline of children in learning to draw at kindergarten. This is a qualitative research using observation, interviews, recording and photography. It is done to study information data that is closely related to the character of the discipline of drawing learning activities and the results of children's drawing. The results of the research can be known from how the teachers teach the children about the character of discipline begins with religious values, with the theme of self, all the senses are told to the child like the five senses done in accordance with the provisions of religion such as starting the right hand to do good as a child to distribute drawing books to his friends, means here the teacher teaches children about discipline through the right hand. Furthermore, in drawing a child does not imitate the image of his friend, of all the results of images made different children, in accordance with ideas, ideas and imagination of each child. About the color drawing crayons are not out of line, the image is clean, and neat. The next child appears to the front of the class to tell the results of the picture, ending with the the teacher tells about the behavior of children during the learning process in order to correct the discipline during the learning drawing took place the results of all discipline children.
\end{abstract}

Keywords: Character, Discipline, Drawing

\section{INTRODUCTION}

Educate according to its potential is very important. Because conformity in educating children affect future developments. The principle of learning to learning while playing, which is used to educate students in the development of cultural arts and character of the nation to get the students to recognize and accept the values of art and culture and character of the nation as a common property. Children at Kindergarten in general do not know what is good and bad for them. Therefore, educators need to imitate and guide in a good direction like character education

Puskur in Suryanto (2011) stated that 18 identifiable characters originating from religion, pancasila, culture, and national education goals are religious, honest, tolerance, discipline, hard work, creative, independent, democracy, curiosity, spirit, nationality, Love the homeland, appreciate achievement, friendly, communicative, love peace, love to read, care environment, social care, and responsibility.

Kindergarten children likened to sprouts that will quickly develop, so that in kindergarten is a golden period, every child is playing the first stone of educational foundation, so that children of optimal kindergarten to absorb science. Character of kindergarten children in the activities and the results of the drawings he made written in accordance with what he expressed.

Every student in drawing generally devotes what is in the depths of the heart expressed through the paper, this is certainly without the personal character of the protege. Characters in drawing need not be searched, because the character will be born alone, and will grow by itself. Gil (1996) beauty in art has a close relationship with the human ability in expression and assess the artwork concerned or associated with the pattern of view and experience of individuals in the creativity.

Purwanto (1997) states that character is a human inner structure that looks at the behavior and actions that are characteristic of the person concerned. Jung (2003) every type of human personality accentuates a process of character or characteristic that affects widely human behavior. In that pattern he says that man has two orientations or a basic tendency in channeling his attention and all his abilities. The tendency to direct and channel outgoing attention is called an extrovert. Conversely, the tendency to direct and channel attention into oneself is called introvert.

The formation of character and character or personality is very important (Suryanto 2011). In the meantime, Puskur in Suryanto (2011) stated that 18 identifiable characters originating from religion, pancasila, culture, and national education goals are religious, honest, tolerance, discipline, hard work, creative, independent, democracy, curiosity , Spirit, nationality, love of the homeland, respect for achievement, friendship / communicative, peace loving, reading, caring environment, social caring, and responsibility.

Samani (2012) character is the basic value that builds one's personal, formed both because of the 
influence of heredity and the influence of the environment that distinguishes with others, and is manifested in the attitude and behavior in everyday life. Daryusti (2011) states that studying the character of things can not be separated from the aesthetic norms embodied in the embodiment. Kostelametz (1978) says that aesthetics is another word of art philosophy, the abstract mind that gives understanding to the artistic experience in general to gain comprehensive relevance. Related to that, Read (1990) says that beauty can be defined as something fun.

On the other hand, Gil (1976) states that beauty in art has a close relationship with the human ability in assessing the work of art concerned to appreciate the beauty. Therefore it should be realized that a beauty will not be separated or strongly associated with the religious view of a person because the life of art with religion as if it has continuity of the realization of artwork. This linkage appears in the activities that arise in the appreciation of the art work in harmony with the religion that is interwoven into a harmonious unity.

From the explanation above, the relationship of character with art is very close with the character will create beautiful artwork that reflects the culture of the nation. In eighteen characters in education one of which is disclosed is discipline, because discipline is very important in everyday life, especially in drawing education.

Among the noble teachings deeply emphasized in Islam is discipline. Such as doing the prayers five times a day overnight in a timely manner. Discipline is one of the doors to success. Expertise in the field of science will have no significant meaning without discipline. Often we meet high knowledgeable people but not able to do much with his knowledge, because of lack of discipline.

On the contrary, many people whose level of knowledge is mediocre but actually achieve tremendous success, because the very discipline in his life is like a religion without blind science, very discipline in his life is like a religion without blind science, science without religion paralyzed. The analogy is simple, we can see the importance of the rule in drawing children taught that in drawing, coloring should not be out of line. Then return the ingredients and drawing tools placed in place. The above example can certainly be drawn into the realm of the wider life. Strictly speaking, discipline is strongly emphasized in the affairs of the world, and moreover the matter of the afterlife. No wonder God orders the believers to get used to discipline. The command, among others, is implicit in the Qur'an of Surat al-Jumuah, verses 9-10.

No educational institution does not teach discipline to its students. Similarly any organization or institution, more so military, must be very stressed discipline to every party involved in it. All must agree, any great plan will fail in the middle of the road when not supported by discipline. According to Kamus Besar Bahasa Indonesia (KBBI), discipline is obedience or compliance with the rules. Obedience means the willingness of the heart to sincerely fulfill every rule that has been made and agreed upon. Living people are not for rules, but everyone needs rules to make life easy for him.

Nowadays, the attitude of discipline is being abandoned by some of our society. They consider discipline to be a mere discourse without them running. Discipline is the same as obeying the rules/regulations. In Indonesia, many Indonesian people are not obedient to the rules / rules that they make their own eg the existence of the rules in the school but still much violated, the sidewalks used as business street seller, civil servants who come home from work not in time, in the community of course There are rules of norm, although the rules are either written or unwritten and so forth. rules of norm, although the rules are either written or unwritten and so forth.

Basically every rule is binding and has goals to be achieved within the members in it. When there are members in it obeying the rules, then he can be called to have carried out the attitude of discipline and if doing otherwise will get sanction. Actually, to be disciplined is easy if we do gradually will turn into a habit.

From these habits will trigger us to behave in accordance with existing regulations. However, today our society is now accustoming to the opposite habit of discipline. Our society seems apathetic to the attitude of discipline that they actually know what is the meaning of discipline. They consider his attitude far from the word/meaning of discipline is something reasonable and understandable. It is so that makes the performance of our society is not optimal and also cause various other problems. To cultivate the attitude of discipline in society today is very important to make a good society life order. As for several ways to foster a culture of discipline in society, among others, change the mindset of society about discipline, planting discipline attitude early on. The existence of strict sanctions for violators, socializationsocialization about the meaning of discipline and so forth.

Discipline is a process of learning to develop habits, self-control and confess personal responsibility to society and the existing rules, then try to be disciplined because discipline is our responsibility.

In the above explanation it is necessary to discipline since early childhood especially in drawing activities. Early childhood is a golden age for children. This golden age has significance and value because it is the foundation for the future of the child. This child's time has the freedom to express without any rules that block and limit it. Therefore, in the golden age it is necessary for parents, teachers, and the community to provide discipline to children so that children can implement discipline from an early age that will affect the discipline of children in adulthood later.

Poerwadarminta in Big Indonesian Dictionary (2005: 28) interpret the word discipline is the exercise of mind and character with the intention that all the attention of children always obey the order in school. Meanwhile, according to Hurlock (2001) in his book Child Development means the behavior of discipline that is the behavior of someone who learns from or 
voluntarily follows a pemimipin. In this case the child is a student who learns from adults about life towards a useful and happy life in the future.

From the above understandings it can be concluded that discipline is the order or rules that must be done in everyday life to train the character of existing members in educational institutions. The main point of the discipline is regulation. Discipline on drawing activities such as children sitting in an orderly listening to the teacher's story on themes, drawing steps, drawings to be made of children, tools to be taken by children, when drawing, finished drawing them straightening materials and tools and tidying up as before.

\section{RESEARCH METHODS}

This research uses qualitative method which is descriptive analysis. The study population was Kindergarten and group B sampler. To find the character of discipline in the activities of the drawing that have been made by the students. Mulyasa (2004) qualitative research aims to gain a determined experience of the experience of the people as perceived by the person concerned. This research is done through three stages of activity, that is. (1) initial activities, (2) core activities, and (3) closing activities. After doing the three stages, the researcher examines the results of drawings made students to reveal the character of the image. This research uses competence-related informants to be able to provide opinions, thoughts, assessments and reinforcements that the researcher of the treatment in the framework of preparing the completion and validate this research. Techniques and data collection tools used in this study using interviews, observation, recording, and shooting. This is done to record data of information related to the character of discipline in drawing activities conducted by kindergarten children. The standard of validity of Guba's (1989) thought, namely: 1) Belief (credibility), 2) transforability, 3) dependability, and 4) affirmation or confirmability.

\section{RESULT AND DISCUSSION}

Discussion of research results conducted by synchronize the results of research with the concepts and theories that have been put forward. According to Bogdan and Biklen (1982) said the theme is a concept or theory arising from the results of research. The results of data interpretation research are formulated into the form of themes and research topics.

In the early activities of the picture we can see the disciplinary child of the character regelius to love God Almighty. For the values of the character of love to God Almighty kindergarten teachers have implemented it began to come to kindergarten children shake hands with teachers mother by saying assamualuaikum, then continued at the morning ceremony, go to class, as well as reading short verses. In the core of the core also children read bismilahhirahmanirrahhim before work and explained about the power of God Almighty, like self by itself. The teacher tells the story and asks who created us, seen some children raised from the number of children raising the hands of the teacher chooses one of them while the other friend does not have a fuss and feel jealous, his friend replied "Allah" all disciplined listen to the answer from his friend after It's teacher and kid applause with joy. Continued the teacher started telling the story about the theme, for the activity of drawing the child heard with discipline pay attention to the explanation of the teacher, the teacher praised the discipline and discipline of his son by applauding everything.

Furthermore, the teacher explained about drawing, the child takes the picture book in the field no one is fighting over the teacher to teach the child that is appointing three children to take the picture book forward and share the picture book to his friends with the pleasure of receiving the drawing book, that way the teacher to share the picture book is not fighting over things These results keep the child from making a fuss when picking up a picture book.

Similarly, crayons are in the Kid's kindergarten lockers pointing among them three people to hand out crayons to their friends orderly so that discipline is maintained. The meaning taken from the discipline is the teacher teaches the child in a way there is a social soul sharing the task to socialize on his friend. Teachers as early childhood educators to instill moral and religious values in accordance with the opinion of Mahyuddin (2011) states Educate children discipline from small to follow the call of Allah SWT and leave all its prohibition, educate children from small noble character.

As children take materials and tools to draw in the set in such a way each locker with no queue to take a picture book because it was sent to share the picture book to their friends with discipline and so did not wrestle then the friend who was sent to go to sit friend who has provided. When they are drawing kindergartners do not imitate the image of their friends, they make their own according to their ideas and ideas, imagination and creativity. From the above explanation that the child has carried out the character of discipline, take time to draw implemented by the child in accordance with applicable provisions.

Pictures that children make with their freedom to be disciplined, in this case is the children make a picture with their own ideas like a child make a picture of his own hands and then given a decoration of a ring attached to the ring finger with spontaneous, and others. The researcher rewards the child that the picture is good. Researchers interviewed this child why the hand drawing was made. This child replied that the word mother of the hand teacher is God's creation is useful for doing fine work, such as to write, eat and pray, and I come to school always greeting with mother and teacher again.

There are children who make flower pictures, junk images, floods, and so forth. In this case, the researcher was moved to hear the conversation from the child that he had known that God created the human hand should we appreciate when the researcher thrust his thumbs 
while praising the good picture, seen on his face feeling happy. So the image made by the child is not a cheat sheet of his friend image but is his own creation, meaning that the child has disciplined himself. The meaning taken from the child is from a small already accustomed discipline has become a common thing that we need to develop for the future of the nation. The success of education, depends on the educator of an early age. Before entering elementary school children should be given the right education and discipline, meaning the influence in accordance with its development (Santoso, 2011).

At the end of the learning process closed by giving apsresiasi to children which means ranging from summarizing the discipline of children in learning to draw to the results of children's drawings. As in the child's discipline in the learning activities of drawing the teacher praised all the children's attitude from his behavior began hearing from the story of the teacher, with the theme of disciplined duck, which is essentially duck in the morning to go foraging along with regularity running always one march lengthwise no first And do not scramble in his journey to the fields, in the afternoon duck back home was so always regular, seen all the ducks are very disciplined in doing the work he always play in the water does not disturb human. From the above explanation the teacher gave an example that animals are only disciplined life. How about mother's child. Well, you see the mother of discipline is not all that good fight. Let's applause everything, pick up a picture book and crayon a motherly child orderly pick it up with three people who distributed the picture book to friends all everything goes in an orderly manner, about the picture made by the child, the image the child made in accordance with the ideas and ideas of each is the same. Everything goes orderly and disciplined.

\section{CONCLUSION}

Based on the results of research and discussion can be put forward several things related to the character of child discipline in the picture in kindergarten. Teachers teach children the character of discipline begins religious values, starting from the theme of self, all the senses are told to the child. Furthermore the senses are done in accordance with the provisions of religion as it begins the right hand to do a good job as the child distributes a picture book to his friend. This means that the teacher teaches children about discipline through hands, then in drawing a child does not imitate his friend's drawing, of all the drawings made by different children, in accordance with the ideas, gagsan and imagination of the child. Crafting color crayons are not out of line, the results are clean, then the child comes forward to tell the drawing result, ends with the teacher's mother telling about the behavior of the child during the learning process takes place the discipline also to the child the results of all discipline.

\section{REFERENCES}

[1] Al-Qur'an Surah Al-Jumuah, verses 9-10. Bandung: CV Dipenogoro

[2] Bogdan, R.C, Biklen, SK. 1982. Qualitative Research for Education: An Introduction to Theory Edition Methods. Boston: Allyn and Bacon Charmaz.

[3] Daryusti. 2011. Hegemony Penghulu in Cultural Perpektif (Revised Edition) Yogyakarta: Cipta Media.

[4] Gil. 2011. Picking Beauty in Art. Jakarta: Varia

[5] Guba, E.G. \& Lincoln, Y. S. 1989. Fourt Generation Evaluation. Newbury Park, Ca: Sage.

[6] Hurlock, B Elizabeth. 2001. Child Development. Volume 1. Jakarta: Erlanga.

[7] Kostelamet. Z. Richard (ed) 1978. Estethics Contenporary, New York: Status of America.

[8] Mahyuddin, 2001. Lecture of Moralism, Jakarta: Kalam Mulia

[9] Suryanto, 2011. Contextual Learning in Building Student Character. Jakarta: Directorate General of Primary Education.

[10] Samani Muchlas and Hariyanto. 2012. The Concept and Model of Character Education. Bandung: Teens Rosdakarya

[11] Read, Herbert. 1990. Understanding Art. Translated by Soedarso SP. Yokyakarta: Sau Dongar Sona

[12] Poerwadarminta, 2005. Big Indonesian Dictionary. Jakarta: Balai Pustaka

[13] Mulyana. 2004. Qualitative Research Methods. Bandung: Alfabeta.

[14] Santoso, Sugeng. 2011. The concept of Early Childhood Education. Jakarta: State University of Jakarta 